\title{
CARTA
}

\begin{abstract}
A Revista Geonomos reproduz neste espaço com a autorização da Sociedade Brasileira de Paleontologia a matéria "Breve apontamentos sobre a proteção legal ao patrimônio paleontológico" de autoria do advogado Rafael de Freitas Valle Dresch, publicada no Boletim Paleontologia em Destaque (Ano 21. n. 56), Boletim Informativo da Sociedade Brasileira de Paleontologia (www.sbpbrasil.org) e que visa informar a legislação que rege a proteção ao patrimônio fossilífero.

Nosso principal objetivo é chamar atenção de todos os profissionais que trabalham em geociências, principalmente, geólogos, biólogos, engenheiros de minas, técnicos em mineração, que os fósseis são patrimônio da União, e, que, portanto não podem, por exemplo, ser comercializados, colecionados em coleções particulares, e, ou, transportados para o exterior sem autorização do DNPM, bem como tornar público ao conhecimento do maior número de profissionais possível, a legislação que deve ser obedecida quando forem encontrados fósseis em situações como, por exemplo, de trabalhos de campo, mapeamento, entre outros.
\end{abstract}

Esperamos que a leitura desta matéria seja um instrumento de esclarecimento e que contribua para que estejamos engajados na proteção deste patrimônio que também é nosso dever como profissionais e estudantes da área de geociências.

Dra. Karin Elise Bhons Meyer

CPMTC/IGC/UFMG

\section{BREVES APONTAMENTOS SOBRE A PROTEÇÃO LEGAL AO PATRIMÔNIO PALEONTOLÓGICO}

\author{
Rafael de Freitas Valle Dresch ${ }^{1}$
}

\begin{abstract}
A SBP fez um levantamento junto a seus associados para saber quais suas principais dúvidas sobre as leis de proteção aos fósseis. Com base nas questões recebidas, nosso advogado Rafael de Freitas Valle Dresch, elaborou um texto contendo as explicações sobre as mesmas como apresentado a seguir: "A principal lei de proteção ao patrimônio fossilífero, também chamado paleontológico, é a Constituição Federal da República Federativa do Brasil que, nos seus artigos 20 e 216, $\mathrm{V}$, determina que esse patrimônio é de propriedade da União. Ademais a legislação infraconstitucional também trata do tema através das seguintes fontes: Portaria n. 55/90 do Ministério da Ciência e Tecnologia (regulamenta a coleta de materiais por estrangeiros); Código Penal (arts. 163 e 180 tratam dos crimes de destruição de coisa alheia e receptação); Lei n. 7.347/85 (trata da ação civil pública em virtude de danos contra o meio-ambiente); Lei n. 8.176/91 (art. 2 trata do crime de usurpação do patrimônio da União quando explorado em desacordo com o título); Lei n. 9.605/98 (arts. 63 e 64 estabelece crimes ambientais contra o patrimônio cultural). Nesses termos é possível afirmar que os fósseis são de propriedade da União (art. 20 e 216, V da Constituição Federal) e, portanto, somente a ela podem pertencer. Tal patrimônio, entretanto, pode ficar sob a guarda de instituições nacionais de ensino e pesquisa,
\end{abstract}

assim como parques temáticos e museus. Quanto à coleta do material fossilífero, os fósseis podem ser coletados por instituições nacionais de ensino e pesquisa e, as instituições estrangeiras poderão participar dessa coleta somente em parceria com instituições nacionais e sob a autorização do DNPM (Departamento Nacional de Produção Mineral), conforme ditames da Portaria n. 55/90 do Ministério da Ciência e Tecnologia. A legislação brasileira estabelece penas para os crimes de destruição e receptação do material (arts. 163 e 180 do Código Penal) bem como para o crime de exploração em desacordo com a autorização (art. $2^{\circ} \mathrm{da}$ Lei n. 8.176/91). Ademais, a Lei n. 9.605/98 estabelece crimes ambientais contra o patrimônio cultural (arts. 63 e 64). O IPHAN (Instituto do Patrimônio Histórico e Artístico Nacional) tem por competência a proteção ao patrimônio cultural brasileiro. Sendo o patrimônio paleontológico considerado patrimônio cultural por determinação legal (art. 216, V da Constituição Federal). O IPHAN deve zelar por medidas de proteção a esse patrimônio. Por outro lado, o DNPM tem a função de fiscalizar e controlar o exercício das atividades relacionadas ao patrimônio fossilífero (coleta, transporte, entre outras), conforme previsão do Decreto-lei n. 4.146/42. O IPHAN, como supracitado, deve buscar a proteção ao patrimônio fossilífero, principalmente, 
através do instituto do tombamento de sítios paleontológicos. No que concerne à legislação estadual, é possível afirmar a sua validade para o território do respectivo Estado da Federação de forma complementar à legislação nacional (arts. 23 e 24 da Constituição Federal). Nos casos de constatações de ilícitos contra o patrimônio paleontológico, deve ser oficializada uma ocorrência junto ao DNPM, órgão encarregado de controlar e fiscalizar as atividades referentes ao patrimônio fossilífero e, também, à Polícia Federal, órgão responsável pela investigação dos crimes contra o patrimônio da União. Cumpre destacar, ainda, que é possível trazer do exterior, fósseis levados ilegalmente através de mecanismos previstos em Convenção Internacional assinada e ratificada pelo Brasil. A convenção Internacional UNIDROIT sobre bens culturais furtados ou ilicitamente exportados, concluída em Roma, em 24 de junho de 1995, foi internalizada pelo Decreto n. 3.166 de 14 de setembro de 1999. O material transportado para o exterior depende de prévia autorização pelo DNPM. Quando no exterior, cada Estado Estrangeiro possui uma legislação própria, mas é aconselhável registrar a entrada desse material junto ao setor aduaneiro para que não haja problemas no retorno. Todo material transportado deve retornar, eis que patrimônio da União. Pelo mesmo motivo, não é permitida a existência de coleções particulares de fósseis. Ademais, é importante frisar que um novo projeto de lei é necessário para sistematizar a legislação atual que apresenta uma série de "brechas" legais, pelas quais aqueles que cometem ilícitos contra o patrimônio paleontológico buscam impunidade. 